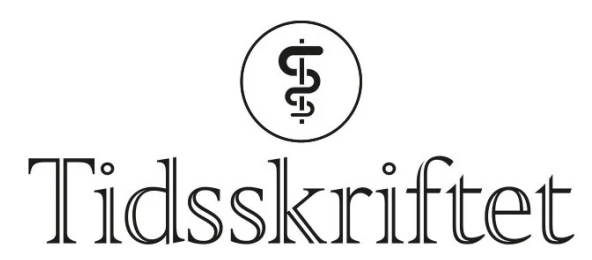

DEN NORSKE LEGEFORENING

\title{
Ketamin ved depresjon - evidens og forslag til praksis
}

KRONIKK

\section{TOR-MORTEN KVAM}

tor-morten.kvam@so-hf.no

Tor-Morten Kvam er spesialist i psykiatri og overlege ved Nordre Østfold DPS, Moss poliklinikk og er tilknyttet Forskningsgruppe Psykiatri og forskningsteamet PsykForsk ved Sykehuset Østfold.

Forfatteren har fylt ut ICMJE-skjemaet og oppgir ingen interessekonflikter.

\section{LOWAN H. STEWART}

Lowan H. Stewart er spesialist i akuttmedisin, medisinsk rådgiver ved forskningsteamet PsykForsk, Sykehuset Østfold, og medisinsk leder ved AxonKlinikken.

Forfatteren har fylt ut ICMJE-skjemaet og oppgir følgende interessekonflikter: Han driver en privat klinikk som behandler depresjoner med ketamin.

\section{ANDREAS WAHL BLOMKVIST}

Andreas Wahl Blomkvist er lege i spesialisering i rus- og avhengighetsmedisin ved Rusavdelingen, Universitetssykehuset Nord-Norge.

Forfatteren har fylt ut ICMJE-skjemaet og oppgir ingen interessekonflikter.

\section{OLE A. ANDREASSEN}

Ole A. Andreassen er spesialist i psykiatri og overlege, professor og leder av SFF NORMENT, Universitetet i Oslo og Oslo universitetssykehus.

Forfatteren har fylt ut ICMJE-skjemaet og oppgir følgende interessekonflikter: Han har mottatt foredragshonorar fra Lundbeck og Sunovion og er konsulent for HealthLytix.

Dagens behandling av alvorlig depresjon er mangelfull, og mange pasienter oppnår ikke ønsket effekt. Ketamin er et nytt behandlingsalternativ, og randomiserte studier viser rask effekt av intravenøs ketamin. Selv om det er noe mangelfull kunnskap om bivirkninger og varighet av effekt, mener vi tiden er inne for å starte klinisk utprøving i Norge. 


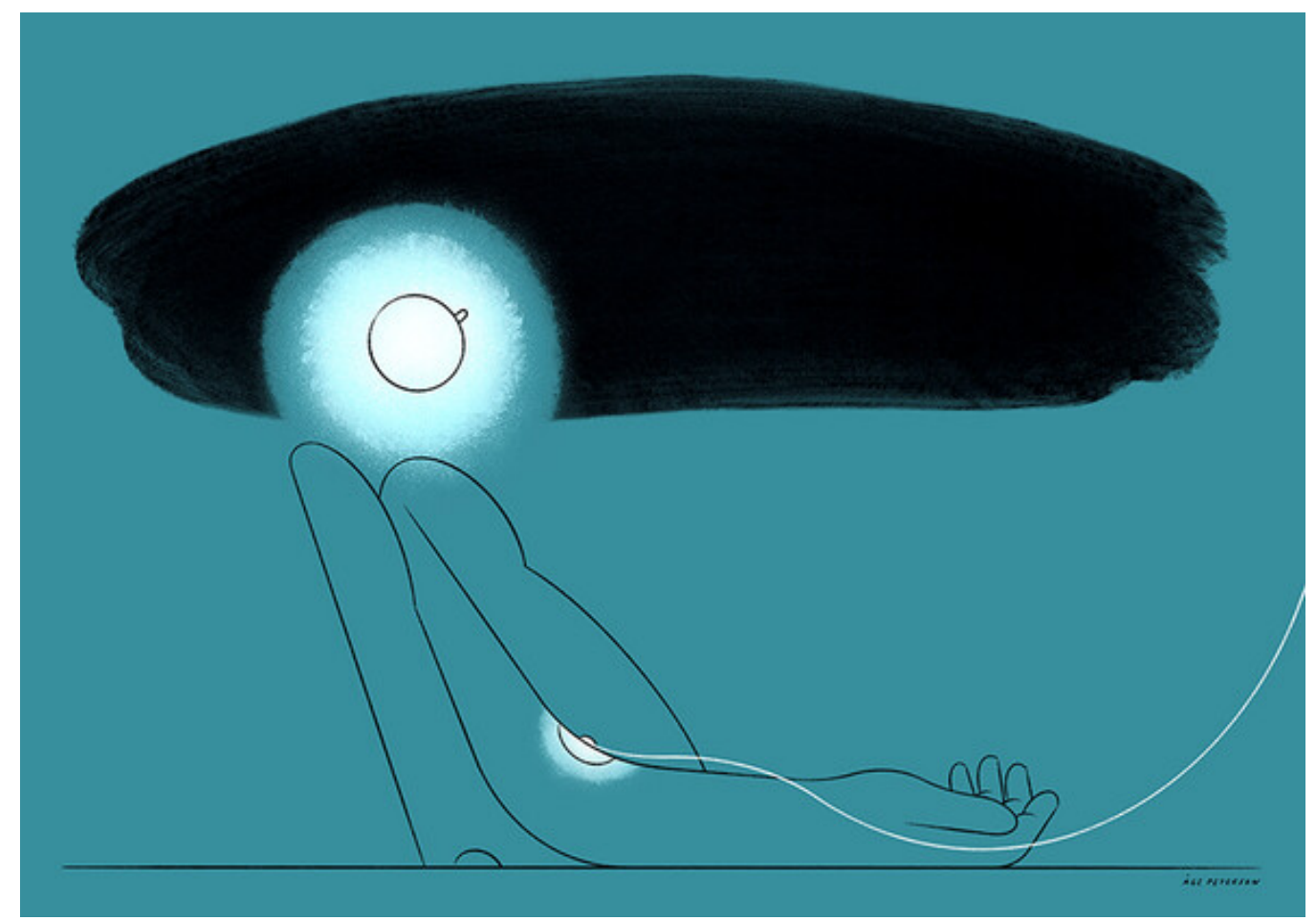

Illustrasjon: Åge Peterson

Det finnes i dag flere behandlingsalternativer for depresjon, både farmakologiske og psykologiske, men alvorlige depresjoner er vanskelig å behandle og en betydelig andel oppnår ikke remisjon. Derfor er det stort behov for nye behandlingsalternativ. Ketamin er et velkjent anestesimiddel som i en serie med studier er vist å ha hurtigvirkende antidepressiv effekt, med akseptable bivirkninger, men varighet må avklares (1). En nesespray med enantiomeren esketamin ble nylig godkjent til bruk mot behandlingsresistent depresjon. Det er behov for skaffe mer kunnskap om varighet av effekt og bivirkninger (1 1 ), men samtidig er det mange med alvorlig depresjon som kan ha nytte av ketamin. Derfor er det startet et utprøvingsprosjekt ved Sykehuset Østfold, og vi foreslår en koordinert klinisk utprøving i Norge.

\section{Depresjon og tilgjengelig behandling}

I Norge er levetidsprevalens for depressiv lidelse på rundt 17 \% (2), som tilsvarer forekomsten internasjonalt, og depresjon er på tredjeplass blant globale årsaker til sykdomsbyrde (ㅉ). I tillegg er det en økt fare for suicid. Effekt av antidepressiva, i hovedsak selektive serotoninreopptakshemmere (SSRI), ses først etter 2 - 4 uker, og effektstørrelsen er liten til moderat (4). Omtrent halvparten av pasienter med depresjon responderer ikke på førstelinjebehandling og rundt 30 \% har ingen respons etter flere typer behandling (므). Behandlingsresistent depresjon, definert som manglende respons på minst to typer antidepressiva med adekvat dose og varighet, er en alvorlig tilstand (므). Dagens antidepressive medikamenter ble utviklet på 1980 - 90 tallet, og det har tilkommet få nye legemidler siden.

\section{Ketamin}

Ketamin består av en racemisk blanding av arketamin og esketamin, og er en nonkompetitiv Nmetyl-D-aspartat (NMDA) glutamatreseptorantagonist med doseavhengig analgetisk og dissosiativ effekt. Ketamin har vært godkjent som anestesimiddel i Norge siden 1972. Hvordan blokkering av NMDA reseptor har effekt på depresjon er ikke kjent fullt ut, men ser ut til å inkludere utskillelse av glutamat, nevroplastisitet og synaptogenese, samt påvirkning av hjernenettverk (ㄱ).

\section{Ketamin ved depresjon}


Én enkeltdose subanestetisk intravenøs racemisk ketamin er vist å være effektivt mot depresjon i flere enn 20 dobbeltblindede, randomiserte, kontrollerte studier (DB-RCT) og flere metaanalyser (8). Virkningen inntreffer vanligvis innen 1 - 2 døgn, og respons- og remisjonsrater er på henholdsvis 70 og $30 \%$ innen 24 timer ()ㅡ). Etter én enkeltdose er tilbakefall innen 1 - 2 uker hovedregelen, selv om 19 - 34 \% ser ut til å ha effekt utover 30 dager (8). Evidensgrunnlaget for effekten av gjentatte doser er begrenset. Flere åpne studier har vist økende respons- og remisjonsrater utover i en behandlingsserie, noe som antyder at enkelte pasienter trenger flere behandlinger for å få full effekt. En DB-RCT på behandlingsresistent depresjon viste effekt av gjentatt dosering to eller tre ganger i uken sammenlignet med placebo (9), mens en annen DB-RCT på et pasientutvalg med kronisk suicidalitet og behandlingsresistent depresjon, hvor nesten halvparten hadde forsøkt elektrokonvulsiv terapi

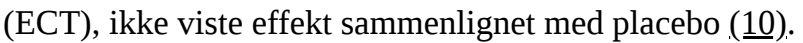

Ketaminbehandling ser også ut til å ha en raskt innsettende effekt på suicidalitet. To metaanalyser av hovedsakelig små studier med kort oppfølgingstid, viser en gunstig effekt på selvmordstanker som er til dels uavhengig av den antidepressive effekten $(\underline{11}, \underline{12})$.

\section{Bivirkninger og risiko}

Bivirkninger ved ketamin er i hovedsak psykiske, kognitive, nevrologiske, urogenitale eller hemodynamiske. De er doserelaterte, milde og oftest forbigående - alvorlige bivirkninger er sjeldne (13). De vanligste bivirkningene går oftest over i løpet av noen få timer etter behandlingen og inkluderer dissosiasjon, økning av puls og blodtrykk, uklart syn, sedasjon, hodepine, rastløshet, svimmelhet og kvalme. Pasienten bør informeres grundig på forhånd om muligheten for dissosiasjon og psykotomimetiske bivirkninger. Iatrogen ketaminavhengighet sees sjelden ved poliklinisk administrasjon av ketamin i depresjonsbehandling, men er noe å være oppmerksom på. Ketamin er grundig utprøvd som anestesimiddel, og risikoen for kardiovaskulær eller respiratorisk påvirkning av subanestetiske doser i depresjonsbehandling er betydelig mindre enn ved bruk i anestesi.

\section{Kontraindikasjoner}

Psykiatriske kontraindikasjoner inkluderer psykose og bipolar lidelse type I i hypoman/manisk fase. Andre relative kontraindikasjoner er ukontrollert hypertensjon, hjerte/-karsykdom, lungesykdom og graviditet/amming. En annen relativ kontraindikasjon er rusavhengighet, selv om det så langt ikke er dokumentert økt risiko for rusavhengighet ved bruk av ketamin i behandling av depresjon (1).

\section{Indikasjoner}

Med tanke på ufullstendige langtidsdata på effekt og bivirkninger, er det i internasjonale retningslinjer anbefalt å reservere intravenøs ketamin til behandlingsresistent depresjon (ㅁ). Dette er samme indikasjon som esketamin nesespray.

\section{Praktisk bruk}

Det er utarbeidet retningslinjer om praktisk bruk av ketamin i USA og Canada $(\underline{8}, \underline{14})$. Her blir behandlingen gitt poliklinisk av leger som har erfaring med bruk av ketamin. Det anses ikke nødvendig å ha anestesipersonell tilstede under behandlingen, men ved administrasjon utenfor sykehus bør nødvendig utstyr for gjenoppliving, samt helsepersonell med erfaring innen hjertelungeredning, være tilgjengelig. Intravenøs infusjon, som gir best biotilgjengelighet, med doser 
mellom 0,5 og 1,0 mg/kg gitt over 40 minutter, er den vanligste administrasjonsformen. Oksygenmetning, blodtrykk og puls bør monitoreres. Den korte halveringstiden gjør at pasientene kan reise hjem innen en time etter infusjonen.

\section{Legemiddelgodkjenning}

Intravenøs ketamin for behandling av depresjon er ikke mulig å patentere, og legemiddelindustrien mangler derfor insentiver for å gjennomføre kostbare kliniske studier for å oppnå markedsføringstillatelse. Esketamin i nesespray er derimot patentert og Janssen har investert i kliniske studier som ga grunnlag for godkjenning for behandlingsresistent depresjon, også i Norge (1ㄷ). Studier som sammenligner esketamin nesespray med intravenøs ketamin mangler, men en metaanalyse antyder bedre effekt av intravenøs administrering (16). Ved utprøvingsprosjektet av ketamin i Sykehuset Østfold er det benyttet intravenøs form av hensyn til effekt, innkjøpskostnader, og antisuicidal effekt.

\section{Forslag til fokusområder for forskning og klinisk utprøving}

Det er flere ubesvarte spørsmål omkring ketamins langtidseffekter, optimal dosering, hyppighet av administrasjon, pasientseleksjon og de underliggende psykofarmakologiske mekanismer (1). Men det er solid evidens for at ketamin er virksom ved behandlingsresistent depresjon og har en akseptabel bivirkningsprofil (1). For å hindre tilfeldig utprøving med mulige uheldige konsekvenser, foreslår vi et nasjonalt samarbeid for å sikre etablering av felles evidensbasert praksis i Norge. Siden langtidsdata fra kliniske studier mangler, bør erfaringer fra klinisk bruk i en naturalistisk setting innsamles på systematisk vis. De faglige retningslinjene fra de nordamerikanske fagmiljøene bør revideres og tilpasses norske forhold $(\underline{8}, \underline{14})$.

\section{LITTERATUR}

1. McIntyre RS, Rosenblat JD, Nemeroff CB et al. Synthesizing the evidence for ketamine and esketamine in treatment-resistant depression: an international expert opinion on the available evidence and implementation. Am J Psychiatry 2021; 178: 383-99. [PubMed][CrossRef]

2. Reneflot A, Aarø LE, Aase H et al. Psykisk helse i Norge. Oslo: Folkehelseinstituttet, 2018. https://www.fhi.no/globalassets/dokumenterfiler/rapporter/2018/psykisk_helse_i_norge2018.pdf Lest 14.9.2021.

3. Knudsen AK, Tollånes MC, Haaland ØA et al. Sykdomsbyrde i Norge 2015. Resultater fra Global Burden of Diseases, Injuries, and Risk Factors Study 2015 (GBD 2015). Oslo: Folkehelseinstituttet, 2017. https://www.fhi.no/globalassets/dokumenterfiler/rapporter/2015/sykdomsbyrde_i_norge_2015.pdf Lest 14.9.2021.

4. Cipriani A, Furukawa TA, Salanti G et al. Comparative efficacy and acceptability of 21 antidepressant drugs for the acute treatment of adults with major depressive disorder: a systematic review and network meta-analysis. Lancet 2018; 391: 1357-66. [PubMed][CrossRef]

5. Rush AJ, Warden D, Wisniewski SR et al. STAR*D: revising conventional wisdom. CNS Drugs 2009; 23: 627-47. [PubMed]

6. Fava M, Davidson KG. Definition and epidemiology of treatment-resistant depression. Psychiatr Clin North Am 1996; 19: 179-200. [PubMed][CrossRef]

7. Moda-Sava RN, Murdock MH, Parekh PK et al. Sustained rescue of prefrontal circuit dysfunction by antidepressant-induced spine formation. Science 2019; 364: eaat8078. [PubMed]

8. Swainson J, McGirr A, Blier P et al. The Canadian Network for Mood and Anxiety Treatments (CANMAT) Task Force Recommendations for the Use of Racemic Ketamine in Adults with Major Depressive Disorder: Recommandations Du Groupe De Travail Du Réseau Canadien Pour Les Traitements De L'humeur Et De L'anxiété (Canmat) Concernant L'utilisation De La Kétamine Racémique Chez Les Adultes Souffrant De Trouble Dépressif Majeur. Can J Psychiatry 2021; 66: 113-25. [PubMed][CrossRef]

9. Singh JB, Fedgchin M, Daly EJ et al. A double-blind, randomized, placebo-controlled, dose-frequency study of intravenous ketamine in patients with treatment-resistant depression. Am J Psychiatry 2016; 173: 816-26. [PubMed][CrossRef] 
10. Ionescu DF, Bentley KH, Eikermann M et al. Repeat-dose ketamine augmentation for treatmentresistant depression with chronic suicidal ideation: A randomized, double blind, placebo controlled trial. J Affect Disord 2019; 243: 516-24. [PubMed][CrossRef]

11. Wilkinson ST, Ballard ED, Bloch MH et al. The effect of a single dose of intravenous ketamine on suicidal ideation: A systematic review and individual participant data meta-analysis. Am J Psychiatry 2018; 175: 150-8. [PubMed][CrossRef]

12. Witt K, Potts J, Hubers A et al. Ketamine for suicidal ideation in adults with psychiatric disorders: A systematic review and meta-analysis of treatment trials. Aust N Z J Psychiatry 2020; 54: 29-45. [PubMed] [CrossRef]

13. Acevedo-Diaz EE, Cavanaugh GW, Greenstein D et al. Comprehensive assessment of side effects associated with a single dose of ketamine in treatment-resistant depression. J Affect Disord 2020; 263: 568-75. [PubMed][CrossRef]

14. Sanacora G, Frye MA, McDonald W et al. A consensus statement on the use of ketamine in the treatment of mood disorders. JAMA Psychiatry 2017; 74: 399-405. [PubMed][CrossRef]

15. Statens legemiddelverk. Spravato (esketamin) nesespray skal kun utleveres etter rekvisisjon fra sykehus. https://legemiddelverket.no/nyheter/spravata-esketamin-nesespray-skal-kun-utleveres-etterrekvisisjon-fra-sykehus Lest 14.9.2021.

16. Bahji A, Vazquez GH, Zarate CA. Comparative efficacy of racemic ketamine and esketamine for depression: A systematic review and meta-analysis. J Affect Disord 2021; 278: 542-55. [PubMed] [CrossRef]

Publisert: 25. oktober 2021. Tidsskr Nor Legeforen. DOI: 10.4045/tidsskr.21.0480

Mottatt 8.6.2021, første revisjon innsendt 23.8.2021, godkjent 14.9.2021.

(c) Tidsskrift for Den norske legeforening 2023. Lastet ned fra tidsskriftet.no 26. april 2023. 